Table 3. DEOXYrIbonucleic ACID AND RIBondCLEIC ACID SYNTHESIS in Normoblastio and Megaloblastio Marrows Grain counts in $24-h r$, cultures

\begin{tabular}{|c|c|c|c|c|}
\hline \multirow{2}{*}{ Label } & \multicolumn{2}{|c|}{ Normal marrows } & \multicolumn{2}{|c|}{$\begin{array}{c}\text { Pernicious anæmia } \\
\text { marrows }\end{array}$} \\
\hline & $\begin{array}{c}\text { Normo- } \\
\text { blasts }\end{array}$ & $\begin{array}{c}\text { Myelo- } \\
\text { cytes }\end{array}$ & $\begin{array}{l}\text { Megalo- } \\
\text { blasts }\end{array}$ & $\begin{array}{l}\text { Myelo- } \\
\text { cytes }\end{array}$ \\
\hline $\begin{array}{l}\text { Formate carbon-14 } \\
\text { (DNA) }\end{array}$ & 120 & 98 & 170 & 100 \\
\hline $\begin{array}{c}\text { Adenine carbon-14 } \\
\text { (DNA + RNA) }\end{array}$ & 245 & 185 & 603 & 295 \\
\hline $\begin{array}{l}\text { Adenine minus } \\
\text { formate }=\mathrm{RNA}\end{array}$ & 125 & 87 & 433 & 195 \\
\hline DNA/RNA & 0.96 & $1 \cdot 10$ & $0 \cdot 39$ & 0.51 \\
\hline
\end{tabular}

anæmia marrows than in myelocytes or normoblasts from normal marrows (inter-marrow variations of grain counts over myelocytes or erythroblasts is \pm 10 per cent).

These observations complement earlier findings by Davidson et $a l .{ }^{1}$ and indicate that in pernicious anæmia marrows deoxyribonucleic acid synthesis is slightly increased in megaloblasts but not in the myelocytes. Synthesis of ribonucleic acid, however, is greatly increased in myelocytes and even more so in megaloblasts of pernicious anæmia marrows. Since in short-term $(6-20 \mathrm{hr}$.) cultures no marked difference was noted between normal and pernicious anæmia serum in the medium, it is suggested that the megaloblastic change takes more than $20 \mathrm{hr}$. to develop. This is in agreement with earlier observations on the formation of megaloblasts in normal marrows cultured in pernicious anæmia serum ${ }^{4}$.

The underlying biochemical defect in the megaloblasts is far from clear. Determinations based on deoxyribonucleic/ribonucleic acid ratios may be misleading, because a greatly increased ribonucleic acid and a slightly less increased deoxyribonucleic acid content may give the erroneous impression of de. ficiency in deoxyribonucleic acid.

L. G. Lajtha

T. Kumatori

Radiobiology Laboratory,

Department of Radiotherapy, Churchill Hospital, Oxford.

1 Davidson, J. N., Leslie, I., and White, J. C., Lancet, i, 1287 (1951); J. Path. Bact., 63, 471 (1951).

"Vilter, R. W., Horrigan, D., Mueller, J. F., Jarrold, T., Vilter, C. F., Hawkins, V., and Seaman, A., Blood, 5, 695 (1950). Vilter, R. W. (Xlazer, H. S., Mueller, J. H., Jarrold, T., Sakurai, K., and Will, J. J., J. Lab. Clin. Med., 42,959 (1953). Glazer, H. S., Mueller J. Lab. Clin. Med., 43,905 (1954).

'Jotter, J. R., J. Amer. Chem. Soc., 76, 2196 (1954). Lajtha, L. G. Nature, 174, 1013 (1954).

- Lajtha, L. G., Clin. Sci., 9, 287 (1950).

${ }^{5}$ Lajtha, L. G., J. Clin. Path., 5, 67 (1952) ; J. Photogr. Sci., 2, 130 $(1954)$.

\section{Effect of Ultra-violet Light on Mouse Skin over a Wide Range of Intensities}

WHETHER the effect on the living skin of a constant dose of ultra-violet radiation is the same if given with high intensity in a short pulse as if given with low intensity ovor a longer period of time has not apparently been recorded. We have therefore examined the tissue injury caused in mouse skin by ultra-violet light of wave-length about $300 \mathrm{~m} \mu$ when the intensity of the incident light was varied from $10^{14}$ to $10^{21} h \mathrm{v} / \mathrm{cm} .^{2} \mathrm{sec}$.

A high-pressure mercury lamp with appropriate filters $\left(2 \mathrm{~mm}\right.$. Jena $W G 7+10 \mathrm{~mm}$. $\mathrm{NiSO}_{4} \cdot 6 \mathrm{H}_{2} \mathrm{O}$,

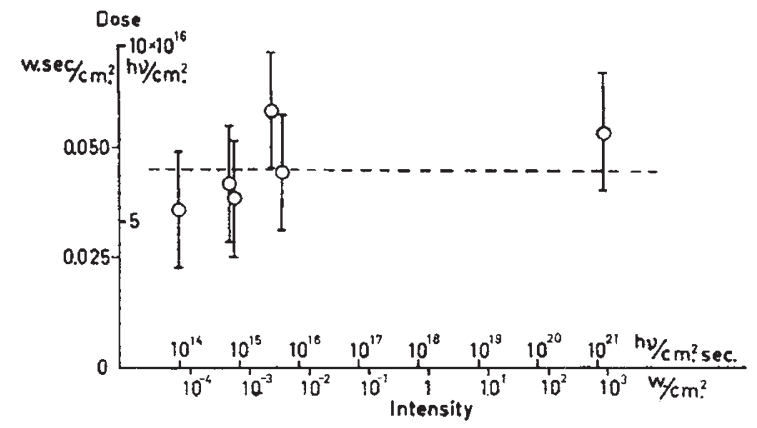

Fig. 1. The relation between light intensity $(\lambda \sim 300 \mathrm{~m} \mu)$ and minimum dose to cause tissue injury in monse skin

$500 \mathrm{gm} . / 1$.$) served as source of light at the lower$ intensities. To obtain different intensities, working distances of about $10,12,35,40$ and $140 \mathrm{~cm}$. were used with exposure times varying from 1 min. up to $120 \mathrm{~min}$. The light pulse of high intensity was obtained from a photolysis flash lamp with maximum emission at about $300 \mathrm{~m} \mu^{1}$ provided with the samo filters. The working distance was $4.5 \mathrm{~cm}$., giving a constant average light-intensity of about $1.3 \times 10^{21}$ $h \nu / \mathrm{cm} .{ }^{2}$ sec. Or about 860 watts $/ \mathrm{cm}^{2}{ }^{2}$; suitable exposure times were 50-150 usec. The intensities and doses were determined by means of chernical actinometry (both uranyloxalate and potassium ferrioxalate).

The mice, a commercial albino stock, were shaved with a barium sulphide paste on the back. They were fastened rigidly without anæsthesia by means of black rubber sheets to plane wooden boards and irradiated on the back through $20 \mathrm{~mm}$. circular openings in the sheets. Each animal was normally irradiated at two positions, both placed over the spine, with about $25 \mathrm{~mm}$. between their centres. A total of about 100 animals were used in the experiments reported here.

The degree of tissue damage was estimated by the leakage into the irradiated areas of intravenously injected Evans blue. A volume of $0.3 \mathrm{ml}$. of the dye solution $(0.5$ per cent in saline) was injected intravenously $20 \mathrm{hr}$. after irradiation. The animals were killed 15 min. after injection. The degree of blueing, estimated by visual colorimetry of the dried skin, was plotted as a function of the irradiation dose. From these curves the minimum dose causing blueing was estimated and is plotted against intensity in Fig. 1. It is evident that this minimum dose is virtually constant over a $10^{7}$-fold change in intensity.

The intensity of the blueing increases with the dose of radiation up to a certain point. The blueing then gradually becomes weaker, probably due to a decrease in blood supply as the damage is increased. This latter limb of the curve is markedly influenced by the light intensity. At the flash intensity the decrease in blueing is evident at much lower doses than in the case of the lower intensities.

$$
\begin{aligned}
& \text { S. Clatesson } \\
& \text { G. WettermakK }
\end{aligned}
$$

Institute of Physical Chemistry,

Institute of Pharmacology, University of Upsala. June 24.

1 Claesson, S., and Lindqvist, L., Arkiv Kemi 11, 535 (1957). Claesson, S., and Wettermark, G., ibid., 11, 561 (1957). 